\title{
Measuring Students' Perceptions of Teacher Involvement in Mathematics Homework Assignments: A Scale Development
}

\author{
Bülent Nuri ÖZCAN ${ }^{1}$ \\ ${ }^{1}$ Faculty of Education, Manisa Celal Bayar University, Manisa, Turkey \\ Correspondence: Bülent Nuri Özcan, Faculty of Education, Manisa Celal Bayar University, Manisa, Turkey. \\ E-mail: bnozcan@gmail.com
}

Received: September 29, 2020 Accepted: November 2, 2020 Online Published: November 12, 2020

doi:10.5539/jel.v9n6p102 URL: https://doi.org/10.5539/jel.v9n6p102

\begin{abstract}
This study aimed to develop a scale to determine students' perceptions of teacher involvement in mathematics homework assignments. An item pool $(\mathrm{n}=30)$ was generated based on a literature review. Based on expert feedback, the number of items was reduced to 21 scored on a 5-point Likert-type scale. A draft named the "Scale of Teacher Involvement in Mathematics Homework Assignments (STIMHA)" was developed after the items were reviewed by a linguist. A pilot study was conducted with six middle school students to check for comprehensibility. The items were revised and finalized based on their feedback. The main study sample consisted of 751 middle school students from four schools in Demirci/Manisa in Turkey during the 2017-2018 academic year. Data were analyzed using the Statistical Package for Social Sciences (SPSS 24.0) and Analysis of Moment Structures (AMOS 21.0). Validity and reliability were established.
\end{abstract}

Keywords: homework, mathematics, teacher involvement, middle school

\section{Introduction}

Homework has been a matter of discussion for nearly a century. The way it is perceived has been changed by the media, policymakers, social trends, and the dominant philosophy of education (Gill \& Schlossman, 2000; Vatterott, 2018). However, it is still a topic of debate both in daily life and in the scientific community. It is regarded as one of the most effective ways of developing successful learning environments and improving academic performance (Coleman, Hoffer, \& Kilgore, 1982; Murillo Torrecilla, \& Martínez-Garrido, 2013). Davidovitch and Yavich (2017) argue that students and parents see it as an indicator of schools' and teachers' quality.

Homework is also considered a battlefield (Cooper, 1989). Corno (1996) defines it as a complex structure affected by different factors. Therefore, students, parents, and teachers have different attitudes towards it (Xu \& Yuan, 2003). It is regarded as a complex structure because it involves different actors, serves different purposes, influences lesson organization, and contains tasks with different levels of difficulty (Dettmers, Trautwein, Lüdtke, Kunter, \& Baumert, 2010).

Despite a lack of consensus on what homework is and how it should be defined, we expect it to be beneficial to learning in a variety of capacities. However, it takes teachers and students and their parents considerable time and energy to complete homework assignments. School administrations, non-governmental organizations, and policymakers also discuss the issue of homework. On the one hand, all stakeholders of education are, one way or another, involved in homework; on the other hand, they discuss the issue depending on their expectations. However, homework has several advantages and disadvantages depending on its nature.

Research has suggested for decades that students should treat homework as an extracurricular activity. Homework is considered crucial because of academic and non-academic outcomes, such as self-regulation and time management (Cooper, 2001; Epstein \& Van Voorhis, 2001).

Teachers regard homework assignments as tasks that students should complete outside the class (Cooper, 1989). Homework is a process that starts with the teacher choosing a relevant subject and content targeting specific learning outcomes and proceeds in the classroom or home and ends back at school (Epstein \& Van Voorhis, 2001; Landers, 2014). According to Vatterott (2018), a good homework assignment should have five qualities; (1) having a clear academic goal (to provide knowledge or to practice skills), (2) allowing students to put new 
knowledge into practice effectively, (3) having a student-appropriate design and options, (4) promoting self-efficacy, and (5) being fun and interesting. However, the quality of homework assignments is also affected by how well teachers know about curricula and their students' skills and needs, as well as parents' characteristics and socioeconomic background (Epstein, 2001).

Teachers have both academic and non-academic expectations from homework assignments (Cooper, 2001; Epstein \& Van Voorhis, 2001), which can be classified under three categories: (1) increasing performance, (2) improving motivation and self-regulation, and (3) establishing a positive relationship between school and home (Trautwein, Niggli, Schnyder, \& Lüdtke, 2009)

Academic outcomes mostly justify homework, and most debates on homework revolve around its relationship with achievement (Landers, 2014), depending on numerous factors (Areepattamannil \& Kaur, 2013; Trautwein, 2007). At first glance, more homework seems to be associated with better academic performance, but homework quality, continuity, and relevant lesson, the time allotted to it, and family support also affect academic performance.

Teachers are primarily responsible for making sure that homework achieves the goals it sets out to accomplish. However, other interested parties' expectations and behaviors (parents) involved in homework affect teacher behavior. Homework helps parents understand and talk about what their children are learning and what they are going through at school. It also provides teachers with an opportunity to ask parents about students' learning. Teachers should, therefore, train parents to become involved in their children's homework assignments (Zhou, Zhou, \& Traynor, 2020).

Although adults think that homework has many benefits, not all students, especially young children, think so. Children have difficulty making sense of homework. Some students state that homework improves their study habits and responsibilities and increases their performance, whereas others find it useless and argue that it evokes negative feelings (Landers, 2013). Students who experience negative feelings are those who perform poorly in class and face difficulties with homework. Being assigned similar, excessive, or hard homework assignments or using extra homework as punishment make students less motivated (Landers, 2013; Trautwein, Köller, Schmitz, $\&$ Baumert, 2002). Xu (2015) argues that homework setting, interest in and reasons for doing homework, benefit expectation, value belief, and teachers' feedback also affect how students perceive homework.

Bembenutty (2011) notes that effective teachers help students develop self-efficacy and time management and self-regulation skills and teach them to take responsibility for their learning and complete homework assignments. Teachers should guide students to carry out learning activities to reach learning goals (Van den Bergh, Ros, \& Beijaard, 2014). They should also give more support to students with more needs. However, they should, in any case, try hard to help students acquire the motivation to finish their homework (Katz, Kaplan, \& Gueta, 2009).

Research focuses on parents more than on teachers (Epstein \& Voorhis, 2001), which may be because homework is regarded as an extracurricular activity over which the latter has no direct control (Núñez, Suárez, Rosário, Vallejo, Cerezo, \& Valle, 2015). Teachers cannot always alter and monitor all variables affecting the homework process, but they can construct the learning process and regulate the homework process to some degree. Teacher involvement in homework can be addressed in two dimensions: (1) setting and assigning a task and (2) giving feedback (Núñez et al., 2015; Zhou et al., 2020).

Murillo and Martinez-Garrido (2014) suggest that teachers should take students' abilities and preferences into account when designing homework. For example, goal-oriented homework makes middle school students more motivated to finish it and benefit from its outcomes and make parents more involved in the education of their children (Epstein \& Van Voorhis, 2001).

The subject area is another factor to consider when designing homework. Students need to devote much time to mathematics (math) because it is one of the most challenging subjects. Studies address the effect of math homework on academic performance from different perspectives. Cooper (2001) argues that math homework affects academic performance little. Fan, Xu, Cai, He and Fan (2017) also report a weak correlation between math/science homework and academic performance. Some other studies show that students who do math homework regularly are likely to perform better in math class (Areepattamannil \& Kaur, 2013; Cooper, Robinson, \& Patall, 2006; Walberg, 1991). However, Trautwein et al. (2002) argue that the amount of homework has no significant effect on academic performance.

Research suggests that how much math homework assignments improve students' performance depends on how well teachers construct the whole process. Grootenboer (2009) states that math homework assignments should be 
rich in accessible and practical concepts and activities, offering multiple solutions, and encouraging meaningful learning and parent engagement.

There is no measure other than the Teacher Homework Involvement Scale (THIS) developed by Xu (2016) to assess teacher involvement in math homework assignments. THIS consists of three subscales; (1) homework quality, (2) feedback quality, and (3) autonomy support. The literature shows that we need a more comprehensive scale that involves more than the subscales of THIS in order to analyze teacher involvement in math homework assignments. We believe that a new and more comprehensive scale will allow us to better understand the issue and contribute to the literature.

This study aimed to develop a scale to measure middle school students' perceptions of teacher involvement in homework assignments. The literature review revealed that the scale could consist of five subscales; (1) attitudes towards homework, (2) homework quality, (3) homework function, (4) feedback quality, and (5) autonomy support. We believe that the new scale will help us construct the process to help both teachers and students achieve maximum benefit from math homework assignments.

\section{Method}

This section addressed sampling, scale development, and data analysis.

\subsection{Sample}

The sample consisted of 751 middle school students (394 girls; 357 boys) from four public schools in Demirci/Manisa in Turkey during the 2017-2018 academic year. A sample of $\geq 300$ is appropriate for data analysis in scale development studies (Tabachnick \& Fidell, 2013). Of participants, 148 (19.7\%) were fifth graders, $251(33.4 \%)$ sixth graders, $173(23 \%)$ seventh graders, and $179(23.8 \%)$ eight graders.

\subsection{Scale Development}

The following are the stages of developing the Scale of Teacher Involvement in Mathematics Homework Assignments (STIMHA).

\subsubsection{Operationalization}

First, a literature review was conducted (Areepattamannil \& Kaur, 2013; Cooper, 2001; Epstein \& Van Voorhis, 2001; Landers, 2014; Trautwein, Niggli, Schnyder, \& Lüdtke, 2009; Xu, 2015; Xu, 2016; Vatterott, 2018). The literature review revealed that STIMHA could consist of five subscales.

\subsubsection{Determination of Scale Objectives}

The goal of STIMHA was to assess teacher involvement in math homework assignments.

\subsubsection{Item Pooling}

An item pool $(\mathrm{n}=30)$ was generated based on the literature review (Areepattamannil \& Kaur, 2013; Cooper, 2001; Epstein \& Van Voorhis, 2001; Landers, 2014; Trautwein, Niggli, Schnyder, \& Lüdtke, 2009; Xu, 2015; Xu, 2016; Vatterott, 2018).

\subsubsection{Expert Feedback}

It is crucial to determine whether items measure what they intend to measure, for which experts can be consulted (Büyüköztürk et al., 2012). Thirteen experts (three mathematics educators, two mathematics teachers, two assessment and evaluation experts, two curriculum development experts, two psychological counseling and guidance experts, and two Turkish educators) were consulted to check the clarity, relevance, and content validity of the STIMHA items.

The experts evaluated the relevance of the items (content validity) on a scale of 1 to $4(1=$ very relevant, $2=$ relevant but needs minor alteration, $3=$ in need of revision, $4=$ not relevant). Content validity ratio (CVR) was calculated using the Davis technique (the number of experts scoring "1" and "2" divided by the total number of experts). The items were found to have a CVR of 0.87 . Based on expert feedback, the number of items was reduced to 21 scored on a 5-point Likert-type scale. The 21-item draft was finalized after the items were reviewed by a linguist.

\subsubsection{Pilot Test}

A pilot test was conducted with six middle school students to check for comprehensibility. The scale items were revised and finalized based on their feedback. The final version of STIMHA was then administered to the main study sample. 


\subsubsection{Data Analysis}

Construct validity was established. Item total correlation was calculated to determine item validity. The construct validity of STIMHA was establish using exploratory factor analysis (EFA) and confirmatory factor analysis (CFA). Lastly, the Cronbach's alpha ( $\alpha$ ) coefficient was used to determine the internal consistency of the scale.

\section{Results}

This section discussed the results of the development and finalization process of STIMHA.

The 21-item STIMHA was applied to the sample $(\mathrm{n}=751)$. Afterward, the sample was divided into two for EFA and CFA (Worthington \& Whittaker, 2006). The data from 310 participants were used for EFA, while that from the remaining 441 was used for CFA.

\subsection{EFA Results}

The EFA data were analyzed using the Statistical Package for Social Sciences (SPSS, version 24.0) at a significance level of 0.05 . Table 1 shows the results.

Table 1. Exploratory factor analysis descriptive characteristics

\begin{tabular}{ll}
\hline Descriptive Characteristics & Statistics \\
\hline Mean & 3.83 \\
Std. Dev. & .58 \\
Minimum & 1.76 \\
Maximum & 4.92 \\
Skewness & -.69 \\
Kurtosis & .28 \\
\hline
\end{tabular}

The skewness coefficient ranged from -1 to +1 , indicating normal distribution. Items $8,12,14$, and 20 were removed because they had a correlation below .30 . The remaining 17 items had item-total correlations greater than .30. The Kaiser-Meyer-Olkin (KMO) measure of sampling adequacy was used to determine whether the sample was adequate $(>.80)$, while Bartlett's test of sphericity was used to determine whether the correlation between the items was adequate for factor analysis $(p<.05)$. The Kaiser-Meyer-Olkin $(K M O)$ was .919 , for which Bartlett's test of sphericity was $\chi^{2}=1660.91, \mathrm{p}=.000$ ), indicating sampling adequacy and correlation between the items for EFA.

The 17 items were loaded on five factors using the principal component analysis. However, EFA revealed a three-factor structure. The scree-plot graph (Figure 1) shows a sharp break in the third component, pointing to a three-factor (component) structure.

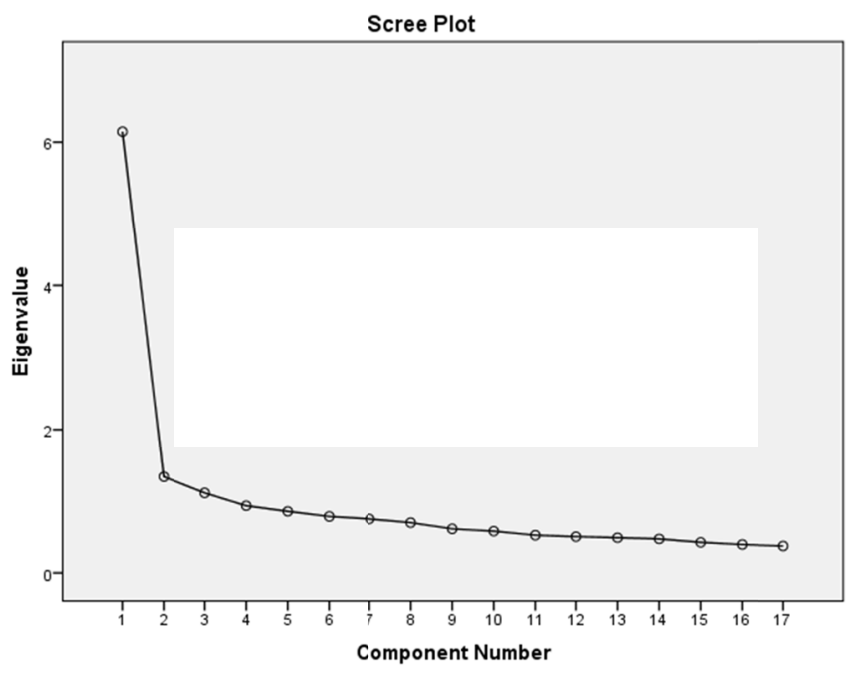

Figure 1. Scree-Plot graph 
Factor 1 consisted of seven items (an eigenvalue of 6.15 ), accounting for $36.15 \%$ of the total variance. Factor 2 consisted of five items (an eigenvalue of 1.34), accounting for 7.88\% of the total variance. Factor 3 consisted of five items (an eigenvalue of 1.11), accounting for $6.55 \%$ of the total variance. STIMHA had a total eigenvalue of 8.60 and explained $50.57 \%$ of the total variance. The variance explained by STIMHA shows that it adequately represents the construct that it intends to measure. In conclusion, STIMHA was a 17 -item scale with three subscales.

Table 2. Exploratory factor analysis results

\begin{tabular}{|c|c|c|c|}
\hline \multirow[t]{2}{*}{ Item No } & \multicolumn{3}{|c|}{ Factor Loading } \\
\hline & $F 1$ & $F 2$ & $F 3$ \\
\hline 4 & .725 & & \\
\hline 5 & .651 & & \\
\hline 3 & .632 & & \\
\hline 6 & .629 & & \\
\hline 7 & .615 & & \\
\hline 9 & .554 & & \\
\hline 11 & .456 & & \\
\hline 15 & & .718 & \\
\hline 13 & & .659 & \\
\hline 16 & & .646 & \\
\hline 17 & & .559 & \\
\hline 1 & & .482 & \\
\hline 18 & & & .746 \\
\hline 21 & & & .626 \\
\hline 19 & & & .609 \\
\hline 10 & & & .516 \\
\hline 2 & & & .421 \\
\hline Eigenvalue $(\mathrm{Sum}=8.60)$ & 6.15 & 1.34 & 1.11 \\
\hline Variance Explained $($ Total $=50.57 \%)$ & $36.15 \%$ & $7.88 \%$ & $6.55 \%$ \\
\hline
\end{tabular}

STIMHA had a Cronbach's alpha of 0.89 . The items had item-total correlations ranging from .356 to .621 . Factors 1, 2, and 3 had a Cronbach's alpha of $0.81,0.74$, and 0.73 , respectively, indicating reliability (Chistiensen, Johnson, \& Turner, 2015; Özlem, Bektaş, Öztürk, \& Horzum, 2014). Based on the shared properties of the items, Factors 1, 2, and 3 were named "Attitude", "Homework Quality", and "Autonomy Support", respectively.

\subsection{Confirmatory Factor Analysis Results}

The Confirmatory Factor Analysis was performed to verify the three-factor structure of the scale. The data were analyzed using the Analysis of Moment Structures (AMOS, version, 21.0). Table 3 shows the results.

Table 3. Confirmatory factor analysis descriptive characteristics

\begin{tabular}{ll}
\hline Descriptive Characteristics & Statistic \\
\hline Mean & 4.0076 \\
Median & 4.0588 \\
Variance & .443 \\
Std. Dev. & .66543 \\
Minimum & 1.35 \\
Maximum & 5.00 \\
Range & 3.65 \\
Interquartile Range & .88 \\
Skewness & -.876 \\
Kurtosis & .944 \\
\hline
\end{tabular}

The Kolmogorov-Smirnov test was used for normality (SPSS, v. 24.0). The skewness ranged from -1.00 to +1.00 , indicating normal distribution.

A path diagram (Figure 2) was obtained for CFA using AMOS. The goodness of fit indices of the model were as 
follows: $\mathrm{CMIN} / \mathrm{DF}=3.16, \mathrm{RMR}=0.060, \mathrm{RMSEA}=0.070, \mathrm{AGFI}=0.874, \mathrm{GFI}=0.904, \mathrm{NFI}=0.861$, and $\mathrm{CFI}$ $=0.90$. These results indicated acceptable fit for CFA results (Schermelleh-Engel, Moosbrugger \& Muller, 2003).

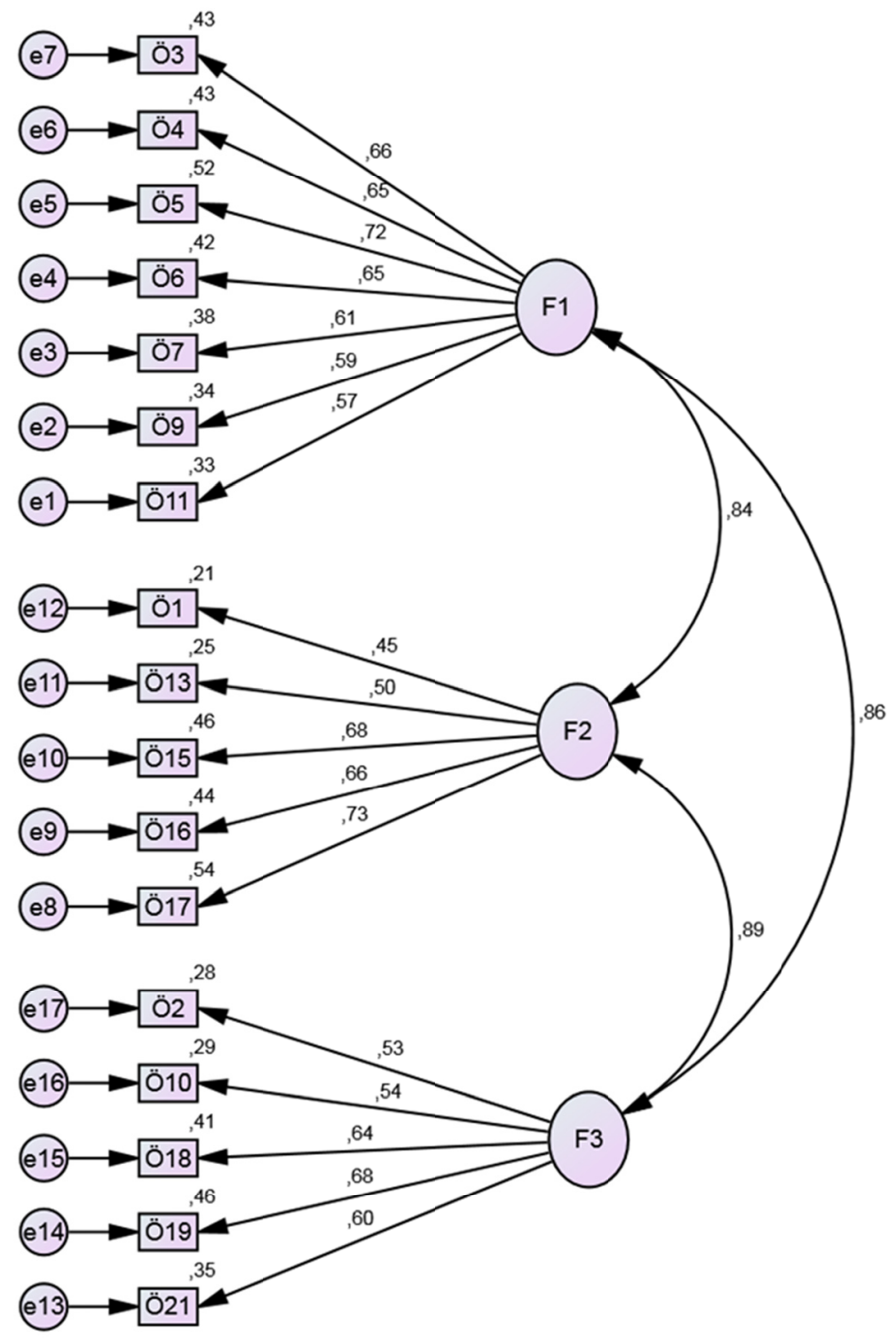

Figure 2. Confirmatory factor analysis path diagram for STIMHA

\section{Discussion}

This study aimed to develop a scale to determine students' perceptions of teacher involvement in math homework assignments. Homework is an integral part of education, believed to contribute to student learning (Tam \& Chan, 2009). Teachers play a crucial role in making sure that students benefit from homework assignments as much as possible. Teachers have the power to manipulate most of the factors affecting the quality of education, and their involvement in homework is of critical importance to maximize the benefit that students can get from it. Therefore, students' perceptions of teacher involvement in homework should be analyzed.

$\mathrm{Xu}$ (2016) was the first to develop a scale to measure teacher involvement in math homework. His scale addressed three constructs (subscales): homework quality, feedback quality, and autonomy support. This study 
was based on the assumption that we need a more comprehensive scale that encompasses more than those three constructs. The preliminary results suggested a five-factor structure to measure teacher involvement in math homework assignments. To that end, a draft, called the Scale of Teachers Involvement in Mathematics Homework Assignments (STIMHA), was developed and analyzed.

The validity and reliability of STIMHA were established using EFA and CFA and Cronbach's alpha. The EFA and CFA results revealed a 17-item three-factor structure; Attitude (seven items), Homework Quality (five items), and Autonomy Support (five items). The analysis showed that the scale items were loaded on three factors instead of five factors initially determined by the researcher based on the literature review. Three of the five subscales were compatible, suggesting that the items related to the remaining two subscales were also loaded on the three subscales. The study yielded a different result than the researcher had predicted based on the literature review and expert feedback, which may be because participants had different perspectives. We believe that it is usual in scale development that items load on components different from those originally envisaged. We failed to fully achieve our intended purpose in terms of subscales. However, similar to Lau, $\mathrm{Ng}$ and Vallett (2019), we can state that STIMHA, all in all, is a valid and reliable scale for assessing students' perceptions of teacher involvement in math homework assignments

\section{Acknowledgments}

The author wishes to extend his gratitude to A. Delil and D. Gogebakan Yildiz for their illuminative discussions during the preparation of this article. The author also wishes to thank Manisa Celal Bayar University for their financial support with project number 2018-017.

\section{References}

Areepattamannil, S., \& Kaur, B. (2013). Relationship of mathematics homework to mathematics achievement among grade 8 students in Singapore. In K. K. University (Ed.), 6th East Asian Regional Conference on Mathematics Education icinde (pp. 363-370). Phuket, Thailand: Khon Kaen University.

Bembenutty, H. (2011). The first word: Homework's theory, research, and practice. Journal of Advanced Academics, 22(2), 185-193. https://doi.org/10.1177/1932202X1102200201

Buyukozturk, Ş., Kılıc Cakmak, E., Akgun, O. E., Karadeniz, Ş., \& Demirel, F. (2012). Scientific Research Methods (22nd ed.). Ankara: Pegem Publishing.

Christensen, B, L., Johnson, R, B., \& Turner, L. A. (2015). Research methods. Design and analysis (Translated by Ahmet Aypay). Ankara: Anı publishing

Coleman, J. S., Hoffer, T., \& Kilgore, S. (1982). High school achievement: Public, Catholic, and private schools compared. New York: Basic Books.

Cooper, H. (1989). Homework. White Plains, NY: Longman. https://doi.org/10.1037/11578-000

Cooper, H. (2001). The battle over homework: common ground for administrators, teachers, and parents (2nd ed.). Thousand Oaks, CA: Corwin Press.

Cooper, H., Robinson, J. C., \& Patall, E. A. (2006). Does homework improve academic achievement? A synthesis of research, 1987-2003. Review of Educational Research, 76(1), 1-62. https://doi.org/10.3102/00346543076001001

Corno, L. (1996). Homework is a complicated thing. Educational Researcher, 25(8), 27-30. https://doi.org/10.3102/0013189X025008027

Davidovitch, N., \& Yavich, R. (2017). Views of Students, Parents, and Teachers on Homework in Elementary School. International Education Studies, 10(10), 90-108. https://doi.org/10.5539/ies.v10n10p90

Dettmers, S., Trautwein, U., Lüdtke, O., Kunter, M., \& Baumert, J. (2010). Homework works if homework quality is high: using multilevel modeling to predict the development of achievement in mathematicsematics. Journal of Educational Psychology, 102(2), 467. https://doi.org/10.1037/a0018453

Epstein, J. L. (2001). School, family, and community partnerships: Preparing educators and improving schools. Boulder, CO: Westview.

Epstein, J. L., \& Van Voorhis, F. L. (2001). More than minutes: Teachers' roles in designing homework. Educational Psychologist, 36(3), 181-193. https://doi.org/10.1207/S15326985EP3603_4

Fan, H., Xu, J., Cai, Z., He, J., \& Fan, X. (2017). Homework and students' achievement in mathematics and science: A 30-year meta-analysis, 1986-2015. Educational Research Review, 20, 35-54. 
https://doi.org/10.1016/j.edurev.2016.11.003

Gill, B. P., \& Schlossman, S. L. (2000). The lost cause of homework reform. American Journal of Education, 109(1), 27-62. https://doi.org/10.1086/444258

Grootenboer, P. (2009). Homework and Learning Mathematics. Australian Primary Mathematics Classroom, 14(4), 11-15.

Katz, I., Kaplan, A., \& Gueta, G. (2009). Students' needs, teachers' support, and motivation for doing homework: A cross-sectional study. The Journal of Experimental Education, 78(2), 246-267. https://doi.org/10.1080/00220970903292868

Landers, M. (2013). Buying in and Checking out: Identity Development and Meaning Making in the Practice of Mathematicsematics Homework. Qualitative Research in Education, 2(2), 130-160.

Landers, M. (2014). Teachers' Homework Strategies in the Context of Ambitious Mathematicsematics Instruction: Developing New Practıces. Ripem, 4(3), 63-86.

Lau, J. M., Ng, K.-M., \& Vallett, D. B. (2019). The counseling training environment scale: initial development and validity of a self-report measure to assess the counseling training environment. Measurement and Evaluation in Counseling and Development, 52(4), 255-273. https://doi.org/10.1080/07481756.2019.1595813

Murillo, F. J., \& Martinez-Garrido, C. (2014). Homework and primary-school students' academic achievement in Latin America. International Review of Education, 60(5), 661-681. https://doi.org/10.1007/s11159-014-9440-2

Murillo Torrecilla, F. J., \& Martínez-Garrido, C. (2013). Homework influence on academic performance: A study of iberoamerican students of primary education. Revista de Psicodidáctica.

Núñez, J. C., Suárez, N., Rosário, P., Vallejo, G., Cerezo, R., \& Valle, A. (2015). Teachers' feedback on homework, homework-related behaviors, and academic achievement. The Journal of Educational Research, 108(3), 204-216. https://doi.org/10.1080/00220671.2013.878298

Ozlem, O. C., Bektaş, M., Ozturk, E., \& Horzum, M. B. (2014Tablet PC acceptance scale-validity and reliability study. Education and Science, 39(176), 69-79. https://doi.org/10.15390/EB.2014.3497

Tabachnick, B. G., \& Fidell, L. S. (2013). Using multivariate statistics (6th ed.). Boston MA: Pearson.

Tam, V. C., \& Chan, R. M. (2009). Parental involvement in primary children's homework in Hong Kong. School Community Journal, 19(2), 81-100.

Trautwein, U. (2007). The homework-achievement relation reconsidered: Differentiating homework time, homework frequency, and homework effort. Learning and Instruction, 17(3), 372-388. https://doi.org/10.1016/j.learninstruc.2007.02.009

Trautwein, U., Köller, O., Schmitz, B., \& Baumert, J. (2002). Do homework assignments enhance achievement? A multilevel analysis in 7th-grade mathematicsematics. Contemporary Educational Psychology, 27(1), 26-50. https://doi.org/10.1006/ceps.2001.1084

Trautwein, U., Niggli, A., Schnyder, I., \& Lüdtke, O. (2009). Between-teacher differences in homework assignments and the development of students' homework effort, homework emotions, and achievement. Journal of Educational Psychology, 101(1), 176. https://doi.org/10.1037/0022-0663.101.1.176

Van den Bergh, L., Ros, A., \& Beijaard, D. (2014). Improving teacher feedback during active learning: Effects of a professional development program. American Educational Research Journal, 51(4), 772-809. https://doi.org/10.3102/0002831214531322

Vatterott, C. (2018). Rethinking homework: Best practices that support diverse needs. ASCD.

Walberg, H. J. (1991). Does homework help? The Second Community Journal, 1, 13-15.

$\mathrm{Xu}, \mathrm{J}$. (2015). Investigating factors that influence conventional distraction and tech-related distraction in mathematics homework. Computers \& Education, 81, 304-314. https://doi.org/10.1016/j.compedu.2014.10.024

$\mathrm{Xu}, \mathrm{J}$. (2016). A study of the validity and reliability of the Teacher Homework Involvement Scale: A psychometric evaluation. Measurement, 93, 102-107. https://doi.org/10.1016/j.measurement.2016.07.012

Xu, J., \& Yuan, R. (2003). Doing homework: Listening to students', parents', and teachers' voices in one urban 
middle school community. School Community Journal, 13(2), 25.

Zhou, S., Zhou, W., \& Traynor, A. (2020). Parent and teacher homework involvement and their associations with students' homework disaffection and mathematicsematics achievement. Learning and Individual Differences, 77, 101780. https://doi.org/10.1016/j.lindif.2019.101780

\section{Appendix A \\ STIMHA-Turkish}

\section{MATEMATÍK ÖDEVİ SÜRECİNDE} ÖĞRETMEN YAKLAŞIMLARI ÖLÇEĞİ

1. Matematik ev ödevlerim bıktıracak kadar uzundur.

2. Matematik öğretmenimin ev ödevlerim hakkındaki değerlendirmelerini önemserim.

3. Matematik öğretmenimin verdiği ev ödevleri sayesinde problem çözmeyi öğreniyorum.

4. Matematik ev ödevlerim derste işlediğimiz konuları anlamama yardımcı olur.

5. Matematik öğretmenimin verdiği ev ödevlerini yaptığımda matematikteki başarım artar.

6. Yaptığım ev ödevlerimle ilgili olarak matematik öğretmenimin yaptığı açıklamalar benim için faydalıdır.

7. Matematik ev ödevlerimiz sınıfta işlediğimiz konularla uyumludur.

8. Matematik öğretmenim seviyeme uygun ev ödevleri verir.

9. Matematik öğretmenim ev ödevlerimde zorlandığımda ipucu verir.

10. Matematik öğretmenim ev ödevlerimi düzenli olarak kontrol eder.

11. Matematik öğretmenimin verdiği ödevler araştırma yapmamı sağlar.

12. Matematik öğretmenim ev ödevlerinin içeriği ile ilgili fikirlerimi dinler.

13. Matematik öğretmenimin verdiği ödevler matematiği yaşamımda kullanmamı sağlar.

14. Matematik öğretmenimin ödevlerim ile ilgili yaptığı değerlendirmeler sonraki ev ödevlerimi daha iyi yapmama yardimcı olur.

15. Matematik öğretmenim ev ödevleriyle ilgili soru sormama izin verir.

16. Matematik öğretmenim ev ödevi verirken gerekli açıklamaları yapar.

17. Matematik ögrretmenim ev ödevleri için yeterli süre verir.
Hiç Katılmıyorum Katılmıyorum Kararsızım Katılıyorum Tamamen

Katılıyorum 


\section{STIMHA-English}

\begin{tabular}{llll}
\hline The Scale of Teacher Involvement in Math Homework Assignments & $\begin{array}{l}\text { Strongly Disagree } \\
\text { Disagree }\end{array}$ & $\begin{array}{l}\text { Neither Agree } \\
\text { Nor Disagree }\end{array}$ & $\begin{array}{c}\text { Agree } \\
\text { Strongly } \\
\text { Agree }\end{array}$ \\
\hline
\end{tabular}

1. Math homework assignments are too long that I get tired of them.

2. I care about my math teacher's assessments on my homework.

3. Math homework assignments help me learn to solve problems.

4. Math homework assignments help me understand the subjects covered in class.

5. Doing math homework assignments improves my math performance.

6. My math teacher's explanations about the homework assignments are useful.

7. Math homework assignments are compatible with the topics covered in class.

8. My math teacher gives homework assignments appropriate to my level.

9. My math teacher gives me tips when I have difficulty doing my homework assignments.

10. My math teacher regularly checks my homework assignments.

11. Math homework assignments encourage me to do research.

12. My math teacher listens to my thoughts on the content of the homework assignments.

13. Math homework assignments allow me to put math into practice in daily life.

14. My math teacher's assessments of a homework assignment help me do better with the next one.

15. My math teacher allows me to ask about the homework assignments.

16. My math teacher explains the homework assignments.

17. My math teacher gives me enough time to do homework assignments.

\section{Copyrights}

Copyright for this article is retained by the author, with first publication rights granted to the journal.

This is an open-access article distributed under the terms and conditions of the Creative Commons Attribution license (http://creativecommons.org/licenses/by/4.0/). 